\title{
EQUILIBRIUM
}

Quarterly Journal of Economics and Economic Policy

2016 VOLUME 11 ISSUE 2, June

p-ISSN 1689-765X, e-ISSN 2353-3293

www.economic-policy.pl

Ključnikov, A., \& Belás, J. (2016). Approaches of Czech Entrepreneurs to Debt Financing and Management of Credit Risk. Equilibrium. Quarterly Journal of Economics and Economic Policy, 11(2), 343-365. DOI: http://dx.doi.org/10.12775/ EQUIL.2016.016

Aleksandr Ključnikov*

Paneuropean University in Bratislava, Slovak Republic

Jaroslav Belás**

Tomas Bata University in Zlin, Czech Republic

\section{Approaches of Czech Entrepreneurs to Debt Financing and Management of Credit Risk}

JEL Classification: $L 26$; $O 16$; $G 32$

Keywords: small and medium enterprises; credit risk; debt financing; gender of entrepreneurs; education of entrepreneurs; company's age and size; Czech Republic

\begin{abstract}
The aim of this article was to define, quantify and compare significant factors of the debt financing in the segment of SMEs. The research focused on the significant differences between groups of entrepreneurs, defined in relation to gender, education, size and age of the company, was carried out in the Czech Republic in 2015 on a sample of 1,141 respondents. We found that while the importance of the credit risk increased during the crisis, the level of knowledge of conditions under which commercial banks provide loans is relatively low between entrepreneurs. Entrepreneurs presume that the credit conditions in commercial banks are not transparent, but agree that the better knowledge of credit criteria
\end{abstract}

(C) Copyright Institute of Economic Research

Date of submission: June 9, 2015; date of acceptance: December 15, 2015

* Contact: aleksadr.kljucnikov@vsp.cz, Paneuropean University in Bratislava, Faculty of Economics and Business, Tematinská 10, 82001 Bratislava, Slovak Republic

** Contact: belas111@gmail.com, Department of Enterprise Economics, Faculty of Management and Economics, Tomas Bata University in Zlin, Mostní 5139, 76001 Zlin, Czech Republic 
allows for easier access to funding. Substantial differences in the assessment of the factors of credit risk by defined groups of entrepreneurs were identified.

\section{Introduction}

Small and medium enterprises (SMEs) and entrepreneurs are currently worldwide recognized to be a key source of dynamism, innovation and flexibility in advanced industrialized countries, as well as in emerging and developing economies. They are the most responsible for net job creation in many countries and make important contributions to innovation, productivity and economic growth. If the SME sector does not have access to external funds for investment, the capacity to raise investment per worker, and thereby improve productivity and wages, is seriously impaired (OECD, 2006; Shuying \& Mei, 2014; Smékalová et al., 2014).

In this context, International Finance Corporation (2013) states that job creation and economic growth through private sector development have become primary areas of focus for policy makers around the world in the aftermath of the global financial crisis. Recent evidence points to the importance of SMEs in providing employment across countries. In addition to employing the largest number of people in aggregate, SMEs generate the most new jobs. But SMEs also face many challenges in day-to-day operations, and these challenges significantly threaten their growth. Access to finance is often cited as one of the primary obstacles that affect SMEs disproportionately, while the lack of data makes it very difficult to determine the exact size of the financing gap.

SMEs can't avoid the general existence of the financial risk that has a certain influence on their production and management. In order to survive in the challenging market competition and put forward effective prevention and control measures, and thus lower the possibility of occurrence of risks to ensure their development, the SMEs need to have a full understanding of the characteristics and the causes of financial risk in relation to their enterprises.

The impact of the financial crisis on the concerned segment of SMEs is currently widely discussed. During the period of financial crisis the credit spread between large and small companies intensifies due to the higher risk perception of the most of the SMEs, which results in the denial for credit. The increased borrowing costs for SMEs increase the probability of their default and hence, make them more vulnerable in the financial distress periods (Ardic, 2012; Casey \& O.Toole, 2014; Kundin \& Erecgovac, 2011; Ozturk \& Mrkaic, 2014). Increasing bank funding costs are associated with 
higher interest rates for the SMEs, but not for the large firms (Ozturk \& Mrkaic, 2014).

The influence of such factors as the size and age of the company seems to influence their access to the credit financing. New and early-stage SMEs are facing more intensive problems with the bank financing than their more established counterparts (North et al., 2010).

In this article, we examine the important factors of credit financing of the companies in the segment of SMEs. We have focused on the importance of credit risk during the crisis, the familiarity of entrepreneurs with the conditions under which banks provide loans to SMEs, the transparency of these conditions and the influence of the better financial knowledge of credit criteria on obtaining better interest rates. Our aim was to find out whether the significant differences in the attitudes of these enterprises depending on the gender or education of their owners, the size and age of the company exist.

\section{Theoretical Background}

According to Fetisovová et al. (2012), financial risks are related to the financial markets development and to the use of single financial instruments. They have a complex nature and can be classified into the following groups: funding risk, credit risk, liquidity risk, the risk of interest rate changes, currency risk, inflation risk and counterparty default risk.

Financial risk exists in all aspects of enterprise financial management, including the raising, use and distribution of capital. The characteristics of financial risk are objectivity, uncertainty, comprehensiveness, and duality. A correct understanding of financial risk and implementation of operable warning methods of financial risk management is of a great significance (Shuying \& Mei, 2014).

According to Bain \& Company, Inc. and the IIF (2013), credit tightening that followed the crisis has affected some SMEs more than others. Significant number of SMEs in the middle range of credit risk is currently unable to access financing. These companies include younger firms, startups and viable older companies with the elevated, but still manageable debt level (Bain \& Company..., 2013). The access to finance is one major challenge for SMEs, which affects them disproportionately more than large firms (International Finance Corporation, 2013), especially in the conditions of the financial distress, when SMEs are often denied for credit (Kundin \& Erecgovac, 2011). 
While small and medium-sized enterprises have their own characteristics that differ them from larger companies, the financial gap seems to be the most significant one (Fetisovová et al., 2012). Many commentators confirm the existence of the financing or financial gap for SMEs. There is no commonly agreed definition of this gap, so this term is basically used to define that a sizeable share of economically significant SMEs cannot obtain financing from banks, capital markets or other suppliers of finance. Furthermore, it is often alleged that i) many entrepreneurs or SMEs that do not currently have access to funds would have the capability to use those funds productively if they were available; ii) but due to structural characteristics, the formal financial system does not provide finance to such entities (OECD, 2006).

IFC Jobs Study (International Finance Corporation, 2013) concludes that to close the financing gap and to reduce the financing constraints, the governments, development finance institutions, financial intermediaries and other private sector actors should all intervene. Regulatory reforms, better financial infrastructure, higher competition in the financial sector, and support measures for financial intermediaries as well as for unserved and underserved groups are among the measures that can improve access to finance, and in turn help job creation. For example, programs aimed at lowering costs of financial services for underserved and unserved SMEs can encourage job creation. Financing SMEs by targeting underserved groups such as women, youth, or poor can provide help where it is needed the most (International Finance Corporation, 2013).

In this context UEAPME (2004) states that recent and on-going developments in the banking sector adds to the concerns of SMEs and will further endanger their access to finance, and that the changes will result in a higher sensitivity for risks and profits in the financial sector. Higher risk awareness in the credit sector, a stronger focus on profitability and the ongoing restructuralization in the financial sector change the framework for SME finance and influence the accessibility of SMEs to finance. The most important change is the introduction of the new rating systems and instruments for credit scoring, which will result in the loss of the personal relationship between SMEs and decision-makers in local bank branches, so the credit application process will become more formal and anonymous. Business start-ups and SMEs with the intention to enter new markets may especially suffer from shortages regarding finance (UEAPME, 2004).

SMEs can significantly profit from the state intervention in the form of the government guarantees in comparison with the larger firms, because according to Ozturk, and Mrkaic (2014), government guarantee of the funding is positively associated with increased finance to all firms, but it doesn't 
have any significant impact on large firms, so this form is suitable to selectively support of SMEs.

Banks represent the main source of access to financing for SMEs in most countries; however, the general characteristics of SMEs have also tended to discourage banks from investing in small firms, and thus, they prefer instead to lend to larger firms, resulting in a worsening of the conditions under which SMEs have to obtain their much needed financing (Chiou et al., 2012).

One of the major constraints in financing the SMEs from the commercial banks, and thus one of the reasons for the extension of the financial gap, is the attitude of the entrepreneurs and the information gap (Feakins, 2004). Commercial banks often think that SME owners do not provide enough information about their firms willingly, and therefore the information gap is a significant problem when providing loans for those firms (Ramlee \& Berma, 2013). Their paper finds that lack of management skills, lack of market power, high information gap and very limited knowledge about management of the business of the SMEs' owners and management is mainly responsible for the lack of access of finance for SMEs.

To reduce the information and financial gap and to get more funds from the banks, SME owners have to be more professional in managing their businesses, observe current market conditions, prepare for any negative future outcomes that can create a problem for their firms, and need to provide the banks with complete data which can help the credit officers to evaluate the loan proposals more efficiently (Ramlee \& Berma, 2013). According to Nkundabanyanga et al. (2014), there is a significant positive relationship between favourable commercial banks' lending terms, financial knowledge of the SME owner and credit availability to SMEs. Information gap between SMEs and banks can be reduced through establishing good relationships with the banks, when the owner of the SME provides all necessary information to the bank managers. It increases the trust of the bank managers and that can help to access funds from the bank (Deakins et al., 2010).

Information about SME creditworthiness and potential is too costly and difficult to obtain. Access to accurate, transparent information has become even more critical since the advent of the financial crisis; banks and other lenders in order to have confidence in the health of SMEs can't any more rely on the traditional methods of collecting information about SMEs which no longer work effectively, and have to develop new techniques to make right credit decisions (Bain \& Company..., 2013). Banks tended to assess creditworthiness by collecting numerous details about each firm before the crisis, including the data about the ownership, assets held both within the 
SME and those outside it that are available as collateral or repayment sources, management, products and the development of the sector of the industry the company belongs to. Today banks are under significant cost reduction pressure, so they are forced to reduce the number of branches and frontline staff who can build personal relationships with customers. Many banks centralized the decision making process about the granting of credits. Valuable information about past relationships with SMEs may simply disappear during the bank consolidation processes. Small business owners, who are looking for new bank relationship, are not able to pass this information to a new bank and must start from scratch to build a new credit relationship. According to the report of Bain \& Company (2013), public officials in the six countries realized during the crisis that the lack of centralized credit data about individual borrowers was one of the reasons of overlending and overborrowing, since banks had an incomplete picture of the total indebtedness of a single borrower.

Higher-quality, lower-cost information is a key to unlocking more sources of finance for SMEs. The availability and the cost of information loom large in SME lending. Several interviewers commented that the high fixed costs of assessing creditworthiness make it challenging for banks to provide relatively small, short term loans, because the loan margin may not be sufficient to cover the fixed up-front costs to conduct due diligence. Similarly, alternative providers of funding in the six countries confirmed that the development of new financing sources has been hampered by a lack of transparent, low-cost information to assess the credit risk of individual loans or portfolios of loans, or to make equity investments in SMEs. The status of information transparency significantly varies across the countries. Interviewers noted that several departments within their central banks, as well as by tax and other official authorities, local or regional chambers of commerce and private sector players, including credit insurance companies, collect a lot of financial information. In spite of that large gap remains, the available information is not often current or linked across the various sources. This type of information is not also timely disseminated. Interviewers identified barriers related to collection, storage, distribution and analysis of this information - all along the creditworthiness assessment process (Bain \& Company..., 2013)

Banks currently require more comprehensive information, including information about ownership, company structure, customer concentration, degree of integration into the supply chain of customers, the share of revenues from exports, banking relationships and guarantees. This level of details allows the bank to understand for example the connection of the SME to the distressed sectors, or the probability of default due to the impact of any individual customer. In addition banks require transparent information 
on business owners. Bank loans are also sensitive to individuals, especially in case of micro-SMEs (Bain \& Company..., 2013).

According to UEAPME, owner and managers must become more aware about the need for transparency towards investors. SME owners have to realize that in the future an access to external finance (venture capital or lending) will depend much more on the transparent and open exchange of information about the situation and the perspectives of their companies. In order to fulfil the new needs for transparency, SMEs will have to use new information instruments (business plans, financial reporting, etc.) and new management instruments (risk-management, financial management, etc.). In the past, business start-ups also very often depended on public support to get access to finance. Increasing risk awareness of the banks and the stricter interpretation of State Aid Rules will further increase the need for public support (UEAPME, 2004).

SMEs need transparent rating procedures. Due to higher risk awareness of the finance sector and the needs of Basel II, many SMEs will be confronted for the first time with internal rating procedures or credit scoring systems by their banks. The bank will require more and better quality information from their clients and will assess them in a new way. Both upcoming developments are already causing increasing uncertainty amongst SMEs. In order to reduce this uncertainty and to allow SMEs to understand the principles of the new risk assessment, UEAPME demands transparent rating procedures - rating procedures may not become a "Black Box" for SMEs: the bank should communicate the relevant criteria affecting the rating of SMEs, the bank should inform SMEs about its assessment in order to allow SMEs to improve (UEAPME, 2004).

In this context, for example Behr and Güttler (2007) see the solution on companies' part that understood banks' approach within the evaluation of creditworthiness and are able to evaluate their expected probability of default (PD) using rating model. This approach could help firms to understand their position from the bank's point of view, help them to prepare all necessary documents about themselves for better assessment of their creditworthiness and will provide the possibility of further negotiations between the bank and the company about credit conditions. According to the author, knowledge of own PD also allows for increasing transparency in credit process and provides better background for the search of external funding sources. If SMEs have sufficient knowledge about their creditworthiness, it may affect management decisions in favour of new sources of external funding due to the expanding range of financing options.

In general, by being the largest creditor of the company, banks can gain a huge influence on the business and dominate in the relationship. The bank 
can exercise this power, as a change to another bank is difficult and costly for the company. The costs occur because the other bank does not posses the same information level as the former one, and might therefore demand a higher risk premium on the interest rate for entering the business relationship (Behr \& Güttler, 2007).

This implies that SMEs will have difficulties if they attempt to switch to a competing bank - the smaller the SME, the greater the information asymmetry faced by a competing bank, meaning an SME is usually locked into a relationship with its current bank, making it easier for the bank to extract extra margin from the relationship. This study finds that in such contexts, banks share merely a part of the benefit linked to having greater knowledge of their customers. Hence, a firm's performance and longlasting relationships increase risk-adjusted profitability. In addition, banks do not have to under-price other services to attract customers and are able to extract risk-adjusted profit from their additional financial services. Small, local banks are thus well placed to exploit hard and soft information when evaluating an SME's creditworthiness and reduce the risk they face (Fredriksson \& Moro, 2014).

Relation with the bank should be of great importance for business owners and managers. There is a positive relationship between the loan managers' trust and short-term access to credit to the SMEs. The information perceived by the loan manager about the SME can reduce the agency cost, as well as the asymmetric information gap between bank and SME. In the event of financial downturn, banks do not refuse to grant more credit to the existing trustworthy customer, while they don't extend credit to any new customer in the same event (Moro \& Fink, 2013).

On the other hand, some evidence implies that the loss of contact with the local bank officers doesn't necessary have a negative impact on financing. The study by Uchida et al. (2012) conducted in Japan did not find any significant relationship between the length of the relationship with the bank and loan officer and relationship lending policies. On top of that, they did not find any significant superiority of soft information gathering between the loan officers from the small banks and large banks.

This study also provides evidence that bank size is an important factor in SME financing. Consistent with the growing literature that goes beyond the conventional paradigm of relationship lending, this study shows that large banks are more aggressive than small banks in SME lending. Moreover, this behaviour is pronounced both in good times and in times of financial crisis. The results support the argument that large banks also have advantages in SME financing because lending technologies may achieve the benefits of economies of scale (Chung-Hua et al., 2012). 
The OECD research framework includes such categories as younger SMEs and younger entrepreneurs with limited trading records and security; female and ethnic minority entrepreneurs (with reputational effects); fast growing firms especially in manufacturing and technology-related sectors; out of the 'norm' situations where SMEs owners have unusual business propositions, such as high growth proposals from SME owners in rural environments (Deakins et al., 2008).

The influence of the personal characteristics of entrepreneurs was discussed in the studies of different authors. Deakins et al. (2010) stated that young entrepreneurs and new businesses have difficulties in gaining loans due to lack of business experience or no track record of the business. North et al. (2010) claimed that the age of the SME and the stage of its development is important, while older SMEs are facing fewer problems with bank financing. These conclusions were rejected by the study of Yildirim et al. (2013), who did not find any significant relationship between firm age and availability of credit on the Turkish market.

Garwe and Fatoki (2012) confirmed that gender does not have any significant impact on SME finance, however, females were more discouraged from bank finance than males, due to the fact that females were in fear of rejection due to lack of education and lack of personal assets or collateral. Gramage (2013) also negated the influence of the gender and the experience of the entrepreneur. According to Irwin and Scott (2010), higher education of the entrepreneurs had an impact on the removal of the problem with the financial restrictions, and it can be generally said that higher education of an entrepreneur helps to remove the problem with the access to finance in comparison with the impact of gender and ethnicity.

Partially opposite results are presented by the study of Gamage (2013). By using a logistic regression analysis, it was found that location of the enterprise, availability of audited financial statements and owner-managers perception of access to finance have significant impact for the availability of credit from commercial banks, while such independent variables such as ownership structure, firm age, industry or sector, the experience of the entrepreneur, asset tangibility, the gender of the entrepreneur, sales growth had no impact on the availability of credit (Gamage, 2013).

The study of Bruns and Fletcher (2008) identifies several factors that are the most important for the decision making process of the loan officer. They found that the availability of collateral, past financial position and business competence are the determinant factors for enhancing credit, and on top of that, CEO's maturity and human capital, business plan and borrowers share to the investment plays an important role for granting the credit. 


\section{Research Objective, Method and Data}

The aim of this article is to define, quantify and compare the approaches of entrepreneurs to the management of credit risk in the segment of SMEs. Within the set objective, we compared the approach of men and women, entrepreneurs with higher education and entrepreneurs with other kinds of education, micro-enterprises and other small and medium-sized enterprises, SMEs doing business for more than 10 years old and younger companies in the segment of SMEs.

The survey of the quality of the business environment was carried out in the first half of 2015 through a questionnaire on a sample of 1,141 respondents in the Czech Republic. The method of choosing companies was as follows. We randomly selected a total of 1650 companies from the Albertina database. These firms were contacted via email and the business owners were asked to complete a questionnaire, which was placed on the website. In cases when the selected company did not respond to our mail in the specified time, we addressed it by telephone.

The structure of the respondents was as follows: $75 \%$ men, $25 \%$ women; $48 \%$ of respondents reported secondary education with graduation, $34 \%$ reported to have university education and $18 \%$ of respondents reported to have secondary education without GCSE; $65 \%$ of the total number of firms were micro enterprises, $27 \%$ were small businesses and $8 \%$ medium-sized firms. $62 \%$ of business owners stated that they are in business for more than 10 years, $21 \%$ of them stated that they are in business for less then 5 years and $17 \%$ of them stated that they are in business in the time interval from 5 to 10 years.

In accordance with the recommendation of the European Commission no. 2003/361/EC, we separated microenterprises employing 0-9 employees, small enterprises (10-49 employees) and medium-sized enterprises (50-249 employees) within the category of SMEs of the questionnaire.

The respondents represented the following sectors: trade (33\%), manufacturing (23\%), construction (14\%), transport (6\%), agriculture (3\%) and other services (39\%).

In this article we set out four scientific hypotheses by the method of expert estimation:

H1: The importance of credit risk increased during the crisis. At least $60 \%$ of entrepreneurs agree with this opinion. We assumed that there are no statistically significant differences in the responses of different groups of entrepreneurs (men and women, entrepreneurs with higher education and other entrepreneurs, and micro-enterprises, small and medium en- 
terprises, enterprises that operate over 10 years and enterprises that operate less then 10 years).

H2: SME entrepreneurs are well informed about the conditions under which banks provide loans. Up to $30 \%$ of entrepreneurs agree with this opinion. We assumed that there are no statistically significant differences in the responses of different groups of entrepreneurs (men and women, entrepreneurs with higher education and other entrepreneurs, and micro-enterprises, small and medium enterprises, enterprises that have operated for over 10 years and enterprises that have operated for less then 10 years).

H3: The conditions under which banks provide loans to SMEs are transparent. Up to $30 \%$ of entrepreneurs agree with this opinion. We assumed that there are no statistically significant differences in the responses of different groups of entrepreneurs (men and women, entrepreneurs with higher education and other entrepreneurs, and micro-enterprises, small and medium enterprises, enterprises that operate over 10 years and enterprises that have operated for less than 10 years).

H4: Better knowledge of credit criteria enables easier access for entrepreneurs to obtain credit and obtain better pricing conditions. At least $60 \%$ of entrepreneurs agree with this opinion. We assumed that there are no statistically significant differences in the responses of different groups of entrepreneurs (men and women, entrepreneurs with higher education and other entrepreneurs, and micro-enterprises, small and medium enterprises, enterprises that operate over 10 years and enterprises that have operated for less then 10 years).

Statistically significant differences between the designated social groups were compared through Pearson statistics at the significance level of 5\%. If the calculated p-value was lower than 5\%, we rejected the null hypothesis and the alternative hypothesis was adopted. The calculations were made through the free software ${ }^{1}$. Statistically significant differences in individual responses were investigated by Z-score. The calculations were made through the free software. ${ }^{2}$

\footnotetext{
${ }^{1}$ Available at: http://www.socscistatistics.com/tests.

${ }^{2}$ Available at: http://www.socscistatistics.com/tests/ztest/Default2.aspx.
} 


\section{Results and Discussion}

Table 1 presents the results of research on the perception of credit risk in the current period.

H1 was partially confirmed. In our research, we found that $63.45 \%$ of Czech entrepreneurs agreed with the statement that the importance of credit risk increased during the crisis. We assumed that there are no statistically significant differences in the responses of different groups of entrepreneurs by gender, education, age and size of the company. This part of $\mathrm{H} 1$ has not been confirmed, because we found that there were statistically significant differences in the overall responses by company size and age ( $\mathrm{p}$-value $=$ 0.0002 / 0.0375). Older firms perceive the growth of credit risk more intensively in comparison to young firms ( $\mathrm{p}$-value $=0.0041$ ).

The important reason for the growth of external financing risk is that the economic crisis has reduced the profitability of SMEs in the Czech Republic, which was confirmed by our previous research. According to the opinion of the Czech entrepreneurs, the average decline in profitability after crisis reached 10,44\% (Belás et al., 2014). We can note in this context that in Slovakia, which has similar economic characteristics as the Czech Republic, the decline in profitability was $12,01 \%$ on average (Belás et al., 2015).

These results are interesting in the context of the study by Kunding and Erecgovac (2011) who stated that during the period of financial distress, the credit spread between large firms and small firms intensifies, and on the grounds of high-risk perception most of the SMEs are denied credit. If the statement is true, then smaller firms should perceive the importance of the credit risk more intensively. On the other hand, our results might indicate that the management and the owners of the smaller companies have inferior or insufficient financial knowledge and lack of management skills, which leads to lower perception of the importance of credit risk during the crisis. The importance of the financial knowledge, management skills, professional approach, knowledge of actual market conditions is emphasized by Ramlee and Berma (2013), Nkundabanyanga et al. (2014), Krasniqi (2010), Carter et al. (2007).

Table 2 presents the results of the research of knowledge of credit conditions by entrepreneurs who operate in the segment of SMEs. 


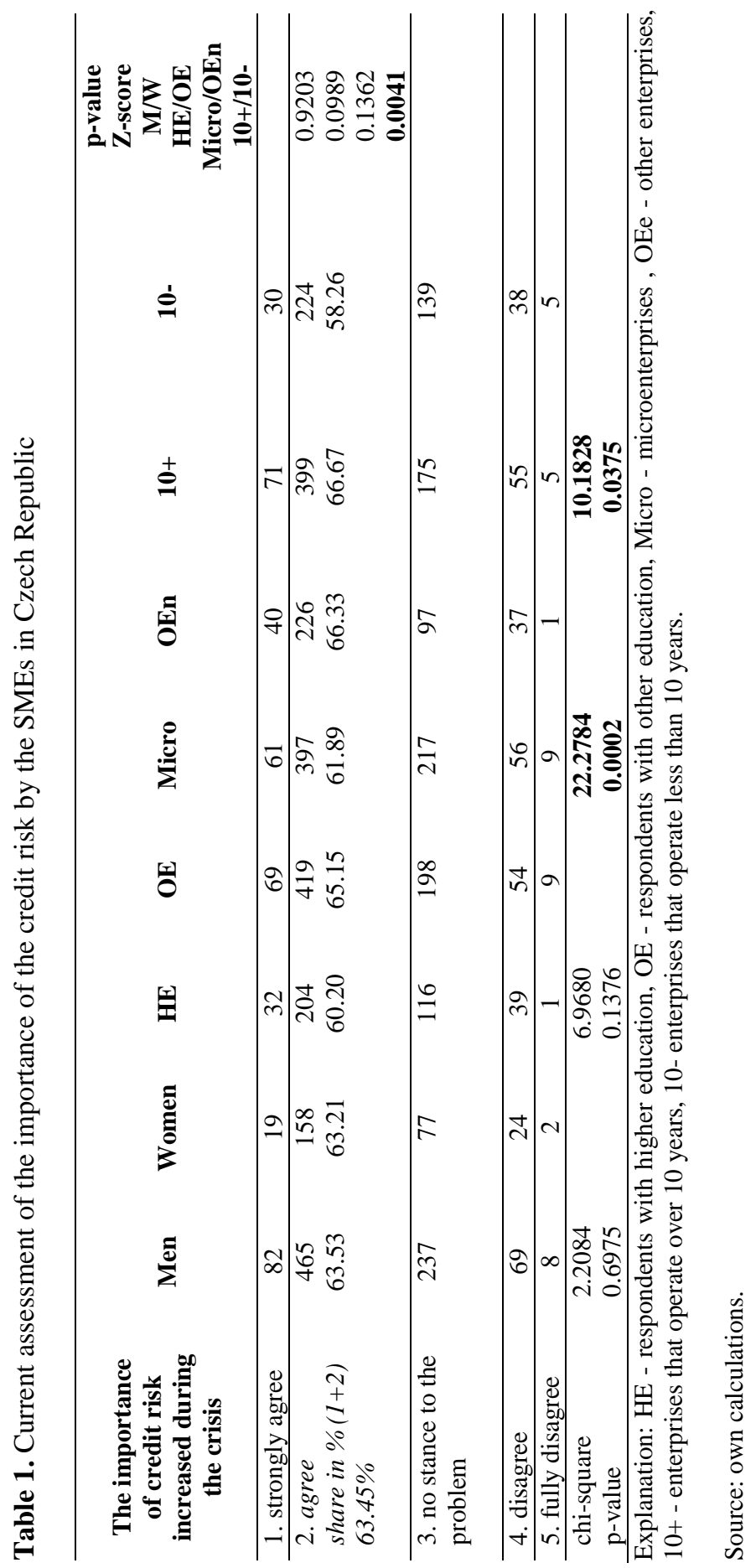




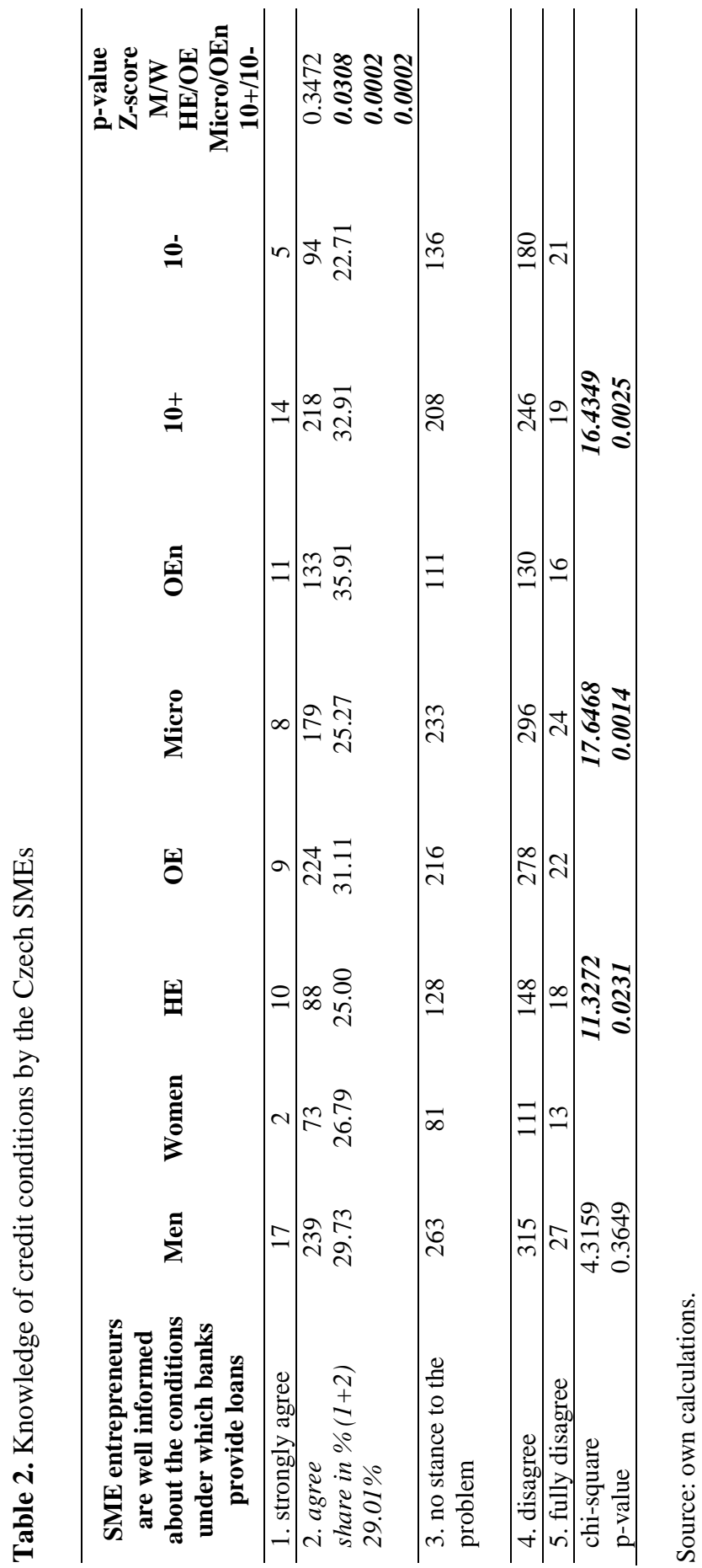


$\mathrm{H} 2$ has been partially confirmed. In our research, we found that only $29.01 \%$ of Czech entrepreneurs in the segment of SMEs agreed with the statement that entrepreneurs are well informed about the conditions under which commercial banks provide loans. At the same time, we found that there were statistically significant differences in the opinions of entrepreneurs according to their education, firm size and age ( $\mathrm{p}$-value $=0.0231 /$ $0.0014 / 0.0025)$. The surprising finding is that less educated entrepreneurs claimed that they knew credit conditions better ( $\mathrm{p}$-value $=0.0308)$. Better knowledge of credit conditions of commercial banks was declared by the larger enterprises $(p$-value $=0.0002)$ and older firms $(p$-value $=0.0002)$.

The importance of the updated knowledge of the financial products and financial management capacity of the SME owners significantly increases the possibility of getting finance. In this context, Kozubíková et al. (2015) states that the knowledge of lending criteria, which represents an important element in the management of SME credit risk, is likely to depend on personal characteristics of entrepreneurs. The evidence presented by Irwin and Scott (2010) states that banks are more comfortable to finance the entrepreneurs with university degree than the secondary or collegeeducated entrepreneurs, due to advanced knowledge of the business propositions and organized loan proposals. The empirical result of the study of Nkundabanyanga et al. (2014) shows that there is a significant positive relationship between favourable commercial banks' lending terms, financial knowledge of the SME owner and credit availability to SMEs.

The fact that larger enterprises declare better knowledge of credit conditions corresponds with the findings of Neuberger (2006) that number of bank relationship increases with a firm size, because a larger firm needs more financing and sometimes it is not possible to get the financing from one bank. Also Moro and Fink (2013) state that larger firm access more short-term credit from the banks, so they have more experience with the bank products.

Table 3 provides an assessment of transparency of credit conditions by entrepreneurs.

H3 has not been confirmed. In our research, only $30.24 \%$ of entrepreneurs presented the view that the conditions under which banks provide loans to SMEs are transparent. We assumed that there are no statistically significant differences in the overall response rate of different groups of entrepreneurs according to gender, education, age and size of the company. We found, however, that there are significant differences in the attitudes of entrepreneurs according to company size (p-value <0.0001). Significant differences were found in the structure of affirmative answers. Men compared to women $(p$-value $=0.0278)$, larger enterprises $(p$-value $=0)$ and 


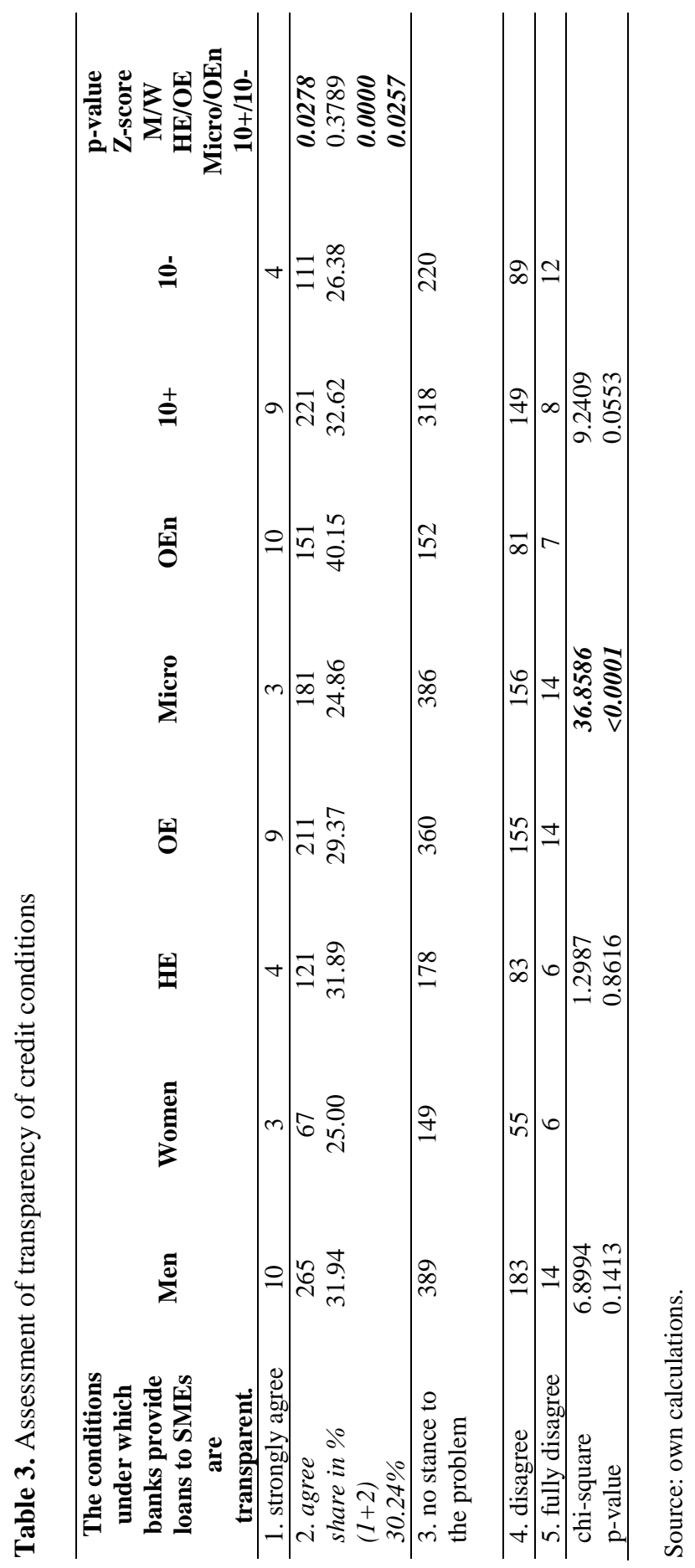


older firms ( $\mathrm{p}$-value $=0.0257$ ) more widely agreed with the statement that credit conditions in commercial banks are transparent.

This finding corresponds to the results of North et al. (2010), who found that new and early stage SMEs are facing more financing problem from the bank than their more established counterparts. Also Deakins et al. (2010) found that young entrepreneurs and new businesses have difficulties in gaining loans, due to lack of business experience or no track record of the business. An interesting fact is that, according to these authors, SMEs were turned down to access funds from the banks due to poor presentation of the loan proposal by the SME owner, although the business was financially solvent and able to repay the loans. Nkundabanyanga et al. (2014) states that updated knowledge of the financial products and financial management capacity of the SME owners significantly increases the possibility of getting finance.

It is remarkable in relation to our findings that the study by Gamage (2013) found that such independent variables as firm age and the experience of the entrepreneur have no impact on the availability of credit.

Table 4 shows the results on how companies perceive the possibility of using the knowledge of the credit conditions for better access to credit.

$\mathrm{H} 4$ has been partially confirmed. We found that $66.43 \%$ of entrepreneurs in the segment of SMEs agreed with the statement that better knowledge of credit criteria provides the entrepreneurs with an easier access to obtain credit and to obtain better pricing conditions. At the same time, we found that there were statistically significant differences in the overall response rate according to age firms $(\mathrm{p}$-value $=0.0105)$. The value of the test criteria ( $p$-value $=0.007$ ) confirmed that there are differences in the structure of affirmative replies in relation to firm age (younger companies agreed with this statement significantly more).

These results fully correspond with the results of Nkundabanyanga et al. (2014), stating the importance of the updated knowledge of the financial products; especially in the part stating that lower interest rates are in direct relation with better knowledge of financial management of SMEs. Also Krasniqi (2010) found that education of both entrepreneurs and employees is important to get the loan due to better business management and financial planning, which is related to the knowledge of credit conditions. 


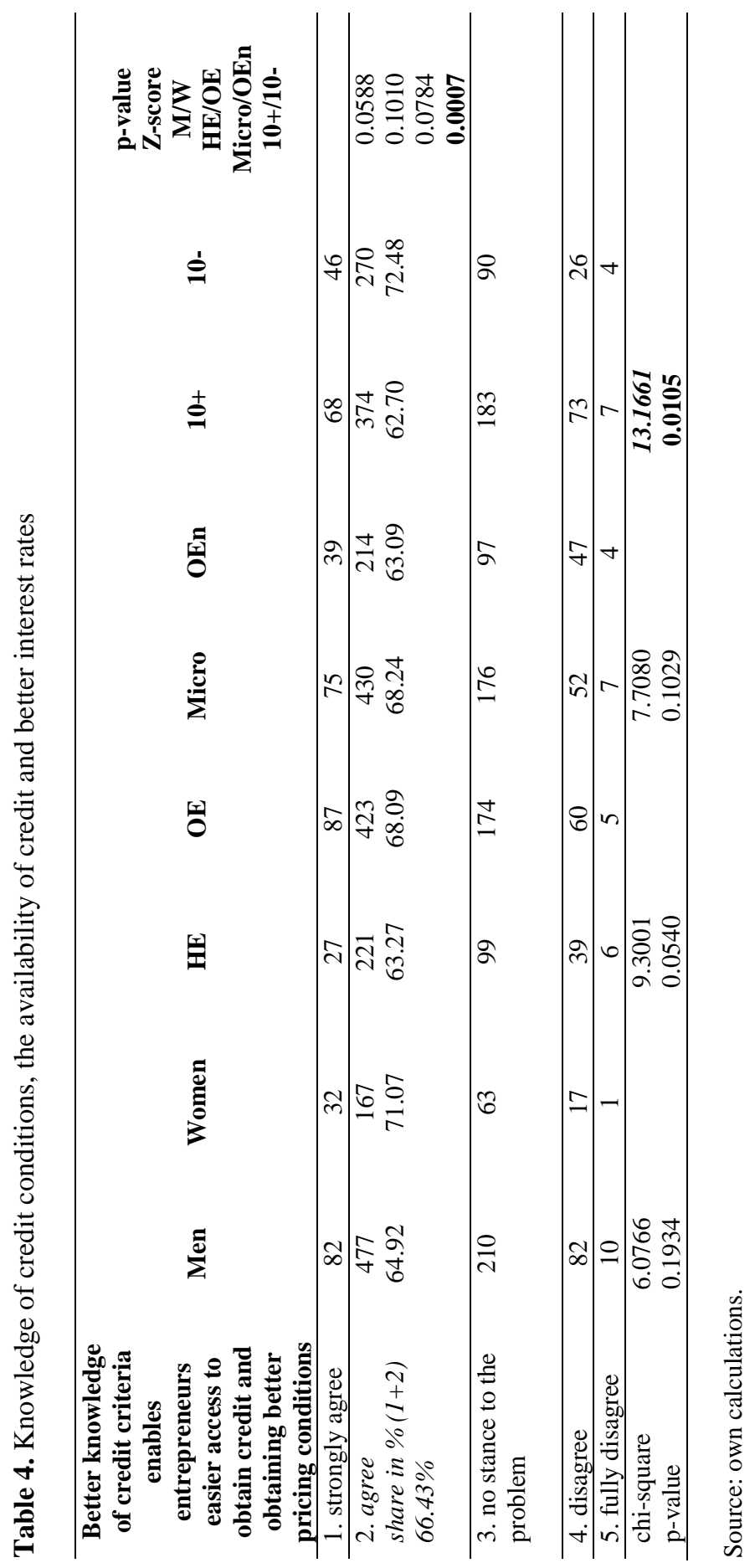


According to the findings of Ramlee and Berma (2013), in order to get more funds from the banks, SME owners have to be more professional in managing their businesses, and more importantly, they have to be very alert about the market's current conditions, which may include the knowledge of financial market conditions. The study by Gamage (2013) found that owner-managers' perception of access to finance have significant impact on the availability of credit from commercial banks.

Studies find that banks in developing economies - compared to those in developed economies - tend to be less exposed to SMEs, and to charge them higher interest rates and fees (Beck et al., 2008). This has been largely due to three factors: 1. informational asymmetries related to SMEs that create risks, e.g. banks are mostly unable to gauge the creditworthiness of SMEs and thus ask for higher charges and collateral requirements; 2. low revenue per client; and 3. the need for local presence, and thus for a large branch network, which may not necessarily be optimal from a cost perspective, especially in a developing country setting. New techniques and technologies are reducing the impact of these factors (IFC, 2013).

Bankers need to take a view on the prospects of the business, not just the future value of an asset. The skills needed to make more subtle judgments - understanding the prospects of the business, having a perspective on the ability and commitment of the owner and management - are complex and different from what was required before the crisis. Many banks have lost personal relationships with their small business customers as they seek to restore profitability. Reductions in banks' frontline staff have vastly reduced their familiarity with these businesses, and severed their personal connections to the owners.

Lack of accurate, comprehensive and timely information seems to be an important problem of the current banking system. As the outlook for a business changes quickly during a downturn, banks need better and different types of information to understand how SMEs' prospects are changing. We heard in Spain that some SMEs lack established relationships with banks that are able to lend to them, because their former banks were acquired or their existing banks have decided they have enough exposure. In such circumstances, SMEs are unable to receive credit for 18 to 24 months, as banks want to use that period to gauge the health of these firms, based on the transactions flowing through their own accounts (Bain \& Company..., 2013).

There are SMEs in the middle ranges of credit risk that are currently unable to access financing. These companies include younger firms, start-ups and viable older companies with manageable but still elevated debt (Bain \& Company..., 2013). 
In Europe, for example, the majority of SMEs maintain a business relationship with just one bank (e.g. 90\% in Denmark and $80 \%$ in Norway). However, the situation of an exclusive relationship with one bank may be contrasted with cases in which SMEs choose instead to source different products from multiple lenders, as is common in Italy and several southern European countries (OECD, 2006).

Credit scoring techniques help to overcome these difficulties. Scoring models evaluate credit risk based on a statistical analysis of the historical relationship between loan defaults and specific characteristics of loans and borrowers. Credit rating methodology is based on methodologies combining quantitative and qualitative data and, in the end, a human assessment. It differs from credit scoring to the extent that it avoids the "black box effects" of credit scoring models (OECD, 2006).

\section{Conclusions}

The aim of this article was to define, quantify and compare the approaches of entrepreneurs to the management of credit risk in the segment of SMEs according to gender, education, size and age of the company.

The most important findings of our research can be summarized as follows. It is obvious and confirmed by the views of our respondents that the importance of credit risk increased during the crisis. Our results also indicate that the management and the owners of the smaller companies have inferior or insufficient financial knowledge and lack of management skills, which leads to lower perception of the importance of credit risk during the crisis. In this context, it is interesting to note that the level of knowledge of credit conditions is relatively low. Only a small part of SME entrepreneurs is well-informed about the conditions under which commercial banks provide loans.

Entrepreneurs in our research quite intensively presented the view that credit conditions in commercial banks are not transparent. The dominant part of the entrepreneurs realizes that better knowledge of credit criteria provides them with an easier access to obtain credit and to obtain better pricing terms of the loan.

We found some differences in the assessment of various factors of credit risk by defined groups of entrepreneurs. Interesting is that older companies perceive the growth of credit risk more intensively in comparison to younger ones. Larger and older firms declared the better knowledge of credit conditions of the commercial banks. The surprising finding is that less educated entrepreneurs argued that they have better knowledge of credit conditions. The self-evaluation of entrepreneurs with the lower level of education 
stating that they have better knowledge of credit conditions seems to be overrated. When assessing the transparency of credit conditions, we found that men, and older and larger firms, showed more optimistic attitudes. Further finding revealed that younger firms have agreed more with the statement that a better understanding of credit conditions facilitates access to credit financing for their companies.

Our study has some limitations, mainly in the limited sample of respondents. Nevertheless, we think that it brings interesting scientific information that can help to understand the opinions of entrepreneurs in the field of cooperation with commercial banks better. Our future research will focus on a deeper understanding of attitudes and motives of entrepreneurs in the field of external financing risk management.

\section{References}

Ardic, O. P., Mylenko, N., \& Saltana, V. (2012). Access to Finance by Small and Medium Enterprises: a Cross-country Analysis with a New Data Set. Pacific Economic Review, 17(4). DOI: http://dx.doi.org/10.1111/j.1468-0106.201 2.00596.x.

Bain \& Company, Inc. and The Institute of International Finance (2013). Restoring Financing and Growth to Europe's SMEs. Retrieved from http://www.bain.com/Images/REPORT_Restoring_financing_and_growth_to_ Europe's_SMEs.pdf.

Behr, P., \& Guettler, A. (2007). Credit Risk Assessment and Relationship Lending: An Empirical Analysis of German Small and Medium-Sized Enterprises. Journal of Small Business Management, 45(2). DOI: http://dx.doi.org/10.1111/j. 1540-627X.2007.00209.X.

Belás, J., Bilan, Y., Ključnikov, A., Vincúrová, Z., \& Macháček, J. (2015). Actual Problems of Business risk in SME Segment. Case Study from Slovakia. International Journal of Entrepreneurial Knowledge, 1(3).

Belás, J., Bartoš, P., Habánik, J., \& Novák, P. (2014). Significant Attributes of the Business Environment in Small and Meduim-Sized Enterprises. Economics and Sociology, 7(3). DOI: http://dx.doi.org/10.14254/2071-789X.2014/7-3/2.

Bruns, V., \& Fletcher, M. (2008). Banks's Risk Assessment to Swedish SME's. Venture Capital, 10(2).

Carter, S., Shaw, E., Lam, W., \& Wilson, F. (2007). Gender, Entrepreneurship, and Bank Lending: The Criteria and Processes Used by Bank Loan Officers in Assessing Applications. Entrepreneurship Theory and Practice, 31(3). DOI: http://dx.doi.org/10.1111/j.1540-6520.2007.00181.x. 
Casey, E., \& O.Toole, C. M., (2014). Bank Lending Constraints, Trade Credit and Alternative Financing During the Financial Crisis: Evidence from European SMEs. Journal of Corporate Finance, 27. DOI: http://dx.doi.org/10.1016/j.j corpfin.2014.05.001.

Deakins, D., North, D., Baldock, R., \& Whittam, G. (2008). SMEs'Access to Finance: Is there still a debt finance gap?. Belfast: Institute for Small Business \& Entrepreneurship.

Deakins, D., Whittam, G., \& Wyper, J. (2010). SMEs Access to Bank Finance in Scotland: an Analysis of Bank Manager Decision Making. Venture Capital, 13(3).

European Association of Craft, Small and Medium-Sized Enterprises, UEAPME (2004). Crafts, Trades and SMEs Need Better Access to Finance. Retrieved form http://www.ueapme.com/docs/pos_papers/2004/041027_SME-finance_ final.doc.

Feakins, M. (2004). Commercial Bank Lending to SMEs in Poland. Small Business Economics, 23.

Fetisovová, E., Hucová, E., Nagy, L., \& Vlachynský, K. (2012). Aktuálne problémy financií malých a stredných podnikov. Bratislava: Ekonóm.

Fredriksson, A., \& Moro, A. (2014). Bank-SMEs Relationships and Banks’ Riskadjusted Profitability. Journal of Banking \& Finance, 41.

Gamage, P. (2013). Determinants of Access to Bank Finance for Small and Medium-sized Enterprises: the Case of Sri Lanka. Corporate Ownership and Control, 10(3).

Garwe, D. K., \& Fatoki, O. (2012). The Impact of Gender on SME Characteristics and Access to Debt Finance in South Africa. Development Southern Africa, 29(3). DOI: http://dx.doi.org/10.1080/0376835X.2012.706040.

Chiou, J., Huang, B., Wu, P., \& Tsai, C. (2012). The Impacts of Diversified Operations on Lending of Financial Institution. Journal of Business Economics and Management, 13(4).

Chung-Hua Shen, Ch., H., Chu, H., \& Yu-Chun Wang, Y. Ch. (2012). Who Furls the Umbrella on Rainy Days? The Role of Bank Ownership Type and Bank Size in SME Lending. Emerging Market Finance and Trade, 48(2).

International Finance Corporation (2013). IFC Jobs Study: Assessing Private Sector Contributions To Job Creation And Poverty Reduction.

Irwin, D. \& Scott, J. M. (2010). Barriers Faced by SMEs in Raising Bank Finance. International Journal of Entrepreneurial Behavior and Research, 16(9). DOI: http://dx.doi.org/10.1108/13552551011042816.

Kozubíková, L., Belás, J., Bilan, Y., \& Bartoš, P. (2015). Personal Characteristics of Entrepreneurs in the Context of Perception and Management of Business Risk in the SME Segment. Economics and Sociology, 8(1). DOI: 10.14254/2071- 789X.2015/8-1/4.

Krasniqi, B. A. (2010). Are Small Firms are Really Credit Constrained? Empirical Evidence from Kosovo?. International Entrepreneurship and Management Journal, 6. 
Kundin, A., \& Erecgovac, R. (2011). Credit Rationing in Financial Distress: Croatia's SMEs Finance Approach. International Journal of Law and Management, 53(1).

Neuberger, D., Rathke, S., \& Schacht, C. (2006). The Number of Bank Relationship of SMEs: A Disaggregated Analysis of Changes in the Swiss Loan Market. Economic Notes, 35(3).

Nkundabanyanga, S. K., Kosozi, D., Nalukenge, I., \& Tauringana, V. (2014). Lending Terms, Financial Literacy and Formal Credit Accessibility. International Journal of Social Economics, 41(5). DOI: http://dx.doi.org/10.1108 /IJSE-03-2013-0075.

North, D., Baldock, R., \& Ekanem, I. (2010). Is There a Debt Finance Gap Relating to Scottish SMEs? A Demand Side Perspective. Venture Capital, 12(3).

Moro, A., \& Fink, M. (2013). Loan Managers' Trust and Credit Access for SMEs. Journal of Banking and Finance, 37.

OECD (2006). The SME Financing Gap. Theory and Evidence. Volume I. Paris: OECD Publications. DOI: http://dx.doi.org/10.1787/9789264029415-en.

Ozturk, B., \& Mrkaic, M. (2014). Access to Finance by SMEs in the Euro Area. What Helps or Hampers. IMF Working Paper, European Department.

Ramlee, S., \& Berma, B. (2013). Financing Gap in Malaysian Small and Medium Enterprises: a Supply-side Perspective. South African Journal of Economics and Management Sciences, 16.

Smékalová, L., Hájek, O., Belás, J., \& Macháček, J. (2014). Perception of Small and Medium Entrepreneurship in the Czech Republic. Journal of Competitiveness, 6(4).

Shuying, Z., \& Mei, Z. (2014). Theory of SMEs Financial Risk Prevention and Control. In International Conference on Education, Management and Computing Technology (ICEMCT 2014).

Uchida, H., Udell, G. F., \& Yamori, N. (2012). Loan Officers and Relationship Lending to SMEs. Journal of Financial Intermediation, 21. DOI: http://dx.doi. org/10.1016/j.jfi.2011.06.002.

Yildirim, H. S., Akci, Y. \& Eksi, I. H. (2013). The Effect of Firm Characteristics in Accessing Credit for SMEs. Journal of Financial Services Marketing, 18(1). DOI: http://dx.doi.org/10.1057/fsm.2012.28. 